\title{
UPAYA PENCEGAHAN DAN SOLUSI TERHADAP TIMBULNYA PENCEMARAN LINGKUNGAN HIDUP DARI BUANGAN LIMBAH INDUSTRI
}

\author{
Siska Ratna Anjarsari, Rochmani \\ Fakultas Hukum, Universitas Stikubank (UNISBANK) Semarang \\ E-mail : siskasra26@gmail.com, rochmani@edu.unisbank.ac.id
}

\begin{abstract}
ABSTRAK
Pencemaran lingkungan hidup akibat buangan limbah industri menjadi perhatian yang tidak pernah surut. Semakin banyak kasus pencemaran lingkungan hidup akibat buangan limbah industri, hal tersebut sangat mengganggu dan meresahkan kehidupan masyarakat serta mengancam kelestarian fungsi lingkungan hidup. Metode penelitian yang digunakan dalam penelitian adalah yuridis normatif dengan melakukan penelusuran terhadap peraturan-peraturan dan literatur- literatur yang berkaitan dengan permasalahan yang diteliti. Tujuan penelitian menjelaskan pencegahan dan solusi terhadap timbulnya pencemaran. Hasil penelitian menunjukkan, upaya pencegahan dan solusi terhadap timbulnya pencemaran lingkungan dengan melakukan perencanana proses produksi yang baik, akurat dan cermat mengurangi penggunaan bahan-bahan kimia pembantu yang rendah beban pencemaran, pengontrolan pemakaian air yang hemat dan efisien, memanfaatkan dan menggunakan kembali (reuse) bahan-bahan kimia yang terdapat dalam limbah cair untuk keperluan produksi serta berupaya memantau limbah hasil pasca proses kegiatan minimasi limbah.
\end{abstract}

Kata kunci : limbah, lingkungan hidup, pencemaran, pencegahan, solusi.

\begin{abstract}
Environmental pollution due to industrial waste disposal is a never-ending concern. There are more and more cases of environmental pollution due to industrial waste disposal, this is very disturbing and disturbing people's lives and threatens the preservation of environmental functions. The research method used in this research is juridical normative by tracing the rules and literature related to the problem under study. The aim of the research is to explain the prevention and solutions to pollution. The results showed that prevention efforts and solutions to the emergence of environmental pollution by planning a good, accurate and accurate production process reduce the use of auxiliary chemicals that are low in pollution load, control water use that is efficient and efficient, reuse and reuse. chemicals contained in liquid waste for production purposes as well as trying to monitor the waste resulting from post-waste minimization activities.
\end{abstract}

Keywords : waste, environment, pollution, prevention, solutions. 


\section{Pendahuluan}

PT. Sango Ceramics Indonesia merupakan salah satu perusahaan besar yang berada di Semarang. Perusahaan ini memproduksi berbagai macam jenis keramik seperti tableware ataupun stoneware, soup plate, soup creamer kembang, salad plate, dinner plate, serta berbagai macam pajangan yang terbuat dari bahan keramik lainnya. Perusahaan ini semua aktivitas produksinya sudah menggunakan mesin-mesin yang canggih dan otomatis (80\% dikerjakan oleh mesin). Penelitian ini menarik untuk diteliti dikarenakan pembuangan limbah industri yang dilakukan PT. Sango Ceramics di Semarang yang mengakibatkan tercemarnya air yang berada di lingkungan sekitar pabrik menimbulkan keresahan warga sekitar. Padahal air merupakan hal yang sangat penting dalam menunjang kehidupan manusia. Proses produksi yang dilakukan PT. Sango Ceramics Indonesia, menghasilkan limbah B3 berupa limbah B3 dari sumber tidak spesifik. Limbah ini tidak berasal dari proses utama, melainkan dari kegiatan pemeliharaan alat, inhibitor, korosi, pelarutan kerak, pencucian, pengemasan dan lain-lain. Limbah ini juga berasal dari sumber yang tidak diduga, misalnya produk kadaluwarsa, sisa kemasan, tumpahan, dan buangan produk yang tidak memenuhi spesifikasi. Proses pengolahan limbah menggunakan sistem stabilisasi, dalam metode ini ditambahkan suatu zat yang dicampur dengan limbah untuk meminimalkan kecepatan migrasi (perpindahan) limbah agar mengurangi toksisitas dari limbah. PT. Sango Ceramics juga melakukan solidifikasi, dimana solidifikasi adalah suatu proses yang menggunakan bahan adiktif berdasarkan sifat fasis alami dari limbah. Adapun pelanggaran yang dilakukan masih adanya limbah B3 yang terbuang di sungai. Berdasarkan uraian diatas penyusun tertarik untuk mengkaji dan menganalisis lebih dalam mengenai: Aspek Hukum Lingkungan Hidup terkait Pengelolaan Limbah Pabrik Dalam Rangka Pencegahan Pencemaran Lingkungan di PT. Sango Ceramics Indonesia.

\section{Rumusan Masalah}

1. Bagaimana aspek hukum lingkungan hidup dalam pengelolaan limbah ramah pabrik di PT. Sango Ceramics Indonesia?

2. Bagaimana upaya pencegahan serta solusi terhadap timbulnya pencemaran lingkungan di PT. Sango Ceramics Indonesia?

\section{Metode Penelitian}

Metode pemdekatan yang digunakan dalam penelitian adalah pendekatan yuridis normatif. Pendekatan yuridis normatif adalah penelitian bahan pustaka sebagai bahan pustaka sebagai bahan dasar untuk diteliti dengan cara meneliti bahan pustaka sebagai bahan dasar untuk diteliti dengan cara mengadakan penelusuran terhadap peraturanperaturan dan literatureliterature yang berkaitan dengan permasalahan yang sedang diteliti.

\section{Pembahasan}

Aspek Hukum Lingkungan Hidup dalam Pengelolaan Limbah Ramah Pabrik di PT. Sango Ceramics Indonesia Penanganan sengketa lingkungan dapat dipulihkan melalui penegakan hukum lingkungan dari siklus pengaturan (regulatory chain) perencanaan kebijakan (policy planning) tentang lingkungan. Penegakan hukum lingkungan di Indonesia mencakup penataan dan penindakan (compliance 
and enforcement) yang meliputi bidang hukum administrasi negara, bidang hukum perdata dan bidang hukum pidana. Sebelum kita membahas lebih jauh tentang penagakan hukum lingkungan, terlebih dahulu kita harus mengetahui definisi dari lingkungan hidup sendiri menurut Undang-Undang Nomor 32 Tahun 2009 adalah kesatuan ruang dengan semua benda, daya, keadaan, dan makhluk hidup, termasuk manusia dan perilakunya, yang mempengaruhi alam itu sendiri, kelangsungan perikehidupan, dan kesejahteraan manusia serta makhluk hidup lain. Selanjutnya kita akan membahas definisi dari pencemaran. Menurut Undang-Undang Nomor 32 Tahun 2009 tentang Perlindungan dan Pengelolaan Lingkungan Hidup, pencemaran adalah masuk atau dimasukkannya makhluk terpadu yang dilakukan untuk melestarikan fungsi lingkungan hidup dan mencegah terjadinya pencemaran dan/atau kerusakan lingkungan hidup yang meliputi perencanaan, pemanfaatan, pengendalian, pemeliharaan, pengawasan, dan penegakan hukum. Namun dewasa ini masih saja terdapat beberapa pihak yang melakukan pencemaran lingkungan hidup, salah satunya yang dilakukan oleh pabrik PT. Sango Ceramics Indonesia di Semarang. Menurut warga, pabrik PT. Sango Ceramics telah mencemari aliran sungai disekitar pabrik. Pencemaran tersebut telah melanggar ketentuan dalam Pasal 69 ayat (1) Undang-Undang Nomor 32 Tahun 2009 tentang Perlindungan dan Pengelolaan Lingkungan Hidup, yang mana setiap orang dilarang untuk :

a. Melakukan perbuatan yang mengakibatkan pencemaran dan/atau perusakan lingkungan hidup; b. Memasukkan B3 yang dilarang menurut peraturan perundangundangan ke dalam wilayah Negara Kesatuan Republik Indonesia;

c. Memasukkan limbah yang berasal dari luar wilayah Negara Kesatuan Republik Indonesia ke media lingkungan hidup Negara Kesatuan Republik Indonesia;

d. Memasukkan limbah B3 ke dalam wilayah Negara Kesatuan Republik Indonesia;

e. Membuang limbah ke mdia lingkungan hidup;

f. Membuang B3 dan limbah B3 ke media lingkungan hidup;

g. Melepaskan produk rekayasa genetik ke media lingkungan hidup yang bertentangan dengan peraturan perundang-undangan atau izin lingkungan;

h. Melakukan pembukaan lahan dengan cara membakar;

i. Menyusun AMDAL tanpa memiliki sertifikat kompetensi penyusun AMDAL; dan/atau

j. Memberikan informasi palsu, menyesatkan, menghilangkan informasi, merusak informasi, atau memberikan keterangan yang tidak benar.

Dapat disimpulkan bahwa pabrik PT. Sango Ceramics telah melanggar beberapa ketentuan dalam Pasal 69 Undang-Undang Nomor 32 Tahun 2009. Maka pihak dari pabrik PT. Sango Ceramics harus melakukan penanggulangan dan pemulihan terhadap lingkungan yang sudah tercemar oleh limbah pabrik tersebut. Sebagaimana yang diatur dalam Pasal 53 UndangUndang Nomor 32 Tahun 2009, setiap orang yang melakukan pencemaran lingkunganhidup wajib hidup, zat, energi, dan/atau komponen lain ke dalam 
lingkungan hidup oleh kegiatan manusia sehingga melampaui baku mutu lingkungan hidup yang telah ditetapkan. Makna dari perlindungan dan pengelolaan lingkungan hidup adalah upaya sistematis dan melakukan penanggulangan lingkungan hidup yang dilakukan dengan :

a. Pemberian informasi peringatan pencemaran dan/atau kerusakan lingkungan hidup kepada masyarakat;

b. Pengisolasian pencemaran dan/atau kerusakan lingkungan hidup;

c. Penghentian sumber pencemaran dan/atau kerusakan lingkungan hidup; dan/atau

d. Cara lain yang sesuai dengan perkembangan ilmu pengetahuan dan teknologi.

Upaya Pencegahan Serta Solusi Terhadap Timbulnya Pencemaran Lingkungan di PT. Sango Ceramics Indonesia Pencemaran lingkungan hidup akibat buangan limbah industri menjadi perhatian yang tidak pernah surut semenjak diberlakukannya UndangUndang Nomor 4 Tahun 1982 yang kemudian diubah menjadi UundangUndang Nomor 23 Tahun 1997 tentang Pengelolaan Lingkungan Hidup.

Semakin banyak kasus pencemaran lingkungan hidup akibat buangan limbah industri, hal tersebut sangat mengganggu dan meresahkan kehidupan masyarakat serta mengancam kelestarian fungsi lingkungan hidup. Pencemaran lingkungan hidup secara teoritis tersebut timbul apabila suatu zat atau energi dengan tingkat konsentrasi yang sedemikian rupa sehingga dapat mengubah kondisi lingkungan.

Pencemaran lingkungan hidup dalam perspektif Undang-Undang adalah masuknya atau dimasukannya makhluk hidup, zat, energi dan komponen lain ke dalam lingkungan hidup oleh kegiatan manusia sehingga kualitasnya turun sampai ketingkat tertentu yang menyebabkan lingkugan hidup tidak dapat berfungsi sesuai dengan peruntukkannya.

Sedangkan berdasarkan aspek teoritis dan yuridis, limbah industri keramik merupakan salah satu komponen yang mengandung bahan organik dan anorganik yang dapat merusak kelestarian fungi lingkungan hidup. Limbah menjadi salah satu permasalahan yang sangat penting dan perlu pengelolaan yang serius agar dampak yang ditimbulkan bisa diatasi. Salah satu teknologi pengeolahan limbah cair yaitu IPAL (Instalasi Pengolahan Air Limbah). Instalasi Pengolahan Air Limbah ini merupakan sebuah teknologi pengolahan limbah cair dari industri yang berfungsi sebagai alat untuk menghilangkan atau mensterilkan pencemaran dari hasil limbah sampai memenuhi baku mutu lingkungan sebelum kemudian dibuang. Adapun beberapa kriteria IPAL yang baik yaitu:

1. Sedikit memerlukan perawatan

2. Aman dalam pengoperasian

3. Produk sampingan seperti lumpu atau sludge

4. Sedikit biaya energi Pada umunya IPAL merupakan gabungan dari proses pengolahan air limbah secara fisik mekanik, biologi dan kimia.

Jika melihat dari hasil limbah pabrik PT. Sango Ceramics ada beberapa pengolahan limbah yang seharusnya dilakukan, agar limbah yang dihasilkan tidak berdampak pada hal negatif saja akan tetapi mempunyai dampak positif berdasarkan pengolahannya, diperlukan regulasi serta jalur koordinasi yang kuat pada pihak PT. Sango Ceramics untuk 
memperhatikan setiap limbah yang dihasilkan agar bisa dinetralisir sebelum dibuang ke lingkungan. Hal tersebut sangat berpengaruh pada keadaan baik dari segi aspek lingkungan maupun masyarakat. Upaya dalam meminimalisasi limbah pabrik adalah :

1. Mengupayakan pengelolaan limbah sebaik mungkin Limbah yang dihasilkan dari proses produksi pabrik merupakan limbah yang berbahaya, karena sebagian pabrik menggunakan bahan-bahan kimia dalam operasional produksi pabrik mereka. Maka dari itulah harus diupayakan langkah-langkah untuk membuat limbah menjadi ramah lingkungan dan tidak mengandung zat-zat yang berbahaya, setelah limbah-limbah yang dihasilkan ini menjadi ramah lingkungan, maka membuangnya langsung ke lingkungan tidak akan menyebabkan pencemaran.

2. Tidak membuang limbah cair langsung ke sumber air Cara bijak yang lainnya adalah tidak membuang limbah pabrik yang cair ke dalam sumber air (baca: proses terjadinya mata air) secara langsung, terlebih tanpa adanya penyaringan dan pengolahan terlebih dahulu. Limbah cair yang langsung berasal dari pabrik, tanpa diolah biasanya akan menyebabkan lingkungan menjadi tercemar. Hal ini karena belum adanya pemisahan antara zat yang berbahaya maupun tidak.

3. Mengubur limbah-limbah yang bersifat organik Untuk limbah pabrik padat, maka perlu adanya tindakan yang berbeda antara limbahlimbah organik dan non organik. Limbah-limbah yang bersifat organik bisa dikubur karena limbah tersebut dapat terurai dengan baik apabila dikubur di dalam tanah (baca: jenis-jenis tanah). Dengan mengubur limbah-limbah organik maka kita hanya mengatasi keberadaan limbah organik saja, namun juga kita akan mendapatkan tanah yang lebih subur dan dapat digunakan untuk berbagai kepentingan tertentu yang pastinya akan bermanfaat.

4. Menggunakan kembali limbahlimbah pabrik yang masih bisa di daur ulang Selain limbah-limbah organik, ternyata limbah anorganik juga mempunyai penanganannya sendiri. Limbah pabrik anorganik yang sulit untuk diurai secara alami maka dapat dipilah-pilah, dan limbah-limbah yang bersifat anorganik ini dapat kita daur ulang menjadi sesuatu yang baru. Limbah anorganik yang masih bisa untuk didaur ulang sebaiknya kita daur ulang saja. Disamping kita membantu menangani persoalan limbah padat pabrik, kita juga dapat menghemat bahan baku.

5. Menanam banyak pepohonan Cera bijaksana yang selanjutnya adalah menanam banyak pohon di sekitar pabrik. Hal ini lebih mengarah ke limbah gas. Limbah pabrik yang bersifat gas biasanya dibuang melalui cerobong asap dan selanjutnya akan mencemari udara. Udara yang tercemar ini akan menyebabkan penipisan pada lapisan ozon pada akhirnya apabila tidak ditangani dengan baik. Maka dari itulah, kita dianjurkan untuk menanam pepohonan untuk dapat menetralisir udara yang telah tercemar tersebut agar tidak terlalu berbahaya.

Penegakan hukum yang paling tepat diterapkan terhadap pencemaran 
limbah PT. Sango Ceramics tersebut adalah dengan hukum keperdataan mengingat sudah terjadinya pencemaran lingkungan hidup yang parah di lingkungan masyarakat. Pemerintah bisa menganakan ganti kerugian terhadap PT. Sango Ceramics dan meminta biaya untuk digunakan sebagai pemulihan lingkungan.

Upaya preverentif atau pencegahan terhadap pencemaran limbah industri keramik adalah tidak nyata yang sulit terelakan dalam konstelasi pembangunan berkelanjutan yang berwawasan lingkungan hidup. Hal penting yang berkaitan dengan upaya preventif atau pencegahan terhadap pencemaran limbah industri keramik, yaitu :

1. Karakteristik Limbah Industri PT. Sango Ceramics Bentuk industri keramik sangat bervariasi seperti permasalahan yang dihadapi oleh industri hilir yang berkonsentrasi pada proses penyempurnaan keramik (finishing). Aktivitas industri keramik pada umunya tetap menghasilkan limbah yang cukup variatif. Proses peyempurnaan keramik mencakup beberapa proses seperti persiapan pencelupan atau pencapan yang meliputi pemasakan (scouring), penggelantangan (bleaching). Proses lainnya adalah pencelupan (dyeing), pencapan (printing) dan penyempurnaan akhir.

2. Upaya-Upaya Pencegahan Pencemaran Limbah Industri PT. Sango Ceramics Pencemaran lingkungan akibat pembuangan limbah industri dapat mengganggu kehidupan masyakat dan menurunkan kualitas lingkungan hidup. Oleh karena itu, beberapa perusahaan industri keramik nasional berusaha mencegah pencemaran tersebut. Berlakunya Undang-Undang Nomor 5 Tahun 1984 merupakan langkah strategisyuridis dalam mencegah berbagai kemungkinan negatif yang timbul akibat aktivitas industri pada umumnya.

Berdasarkan realitas permasalahan limbah industri termasuk intensitas pencemaran limbah industri keramik pada berbagai wilayah Indonesia. Upaya-upaya pencegahan oleh perusahaan-perusahaan industri keramik sangat fundamental. Berikut ini beberapa upaya pencegahan pencemaran limbah PT. Sango Ceramics :

a. Penerapan Teknologi dan Produk Bersih Program produk bersih memiliki makna penting untuk menciptakan suatu produk dengan menggunakan teknologi ramah lingkungan. Menurut Badan Pengendalian Dampak Lingkungan (BAPEDAL) yang memperkenakan pada tahun 1993, adalah strategi pengelolaan lingkungan hidup yang bersifat pencegahan (preventive) dan terpadu. Penerapan teknologi bersih secara aktual dapat diharapkan untuk mencegah pencemaran lingkungan hidup akibat buangan limbah industri, tetapi yang menjadi hambatan adalah kualitas sumber daya manusia, dana pendukung operasional, kesadaran serta disiplin dalam menjalankan rencana-rencana kegiatan di lapangan.

b. Pengolahan Limbah Cair Industri PT. Sango Ceramics Upaya pegolahan limbah cair industri keramik membutuhkan ketegasan terhadap konsep yang akan digunakannya yaitu mengutamakan salah satu seperti proses kimia, biologi, dan fisika atau 
menggabungkan ketiganya. Upaya tersebut disesuaikan dengan kondisi kemampuan perusahaan industri keramik bersangkutan menerapkan dan memanfaatkan konsep pengolahan yang tersedia dalam rutinitas kegiatan bisnisnya.

c. Minimasi Limbah Cair Industri PT. Sango Ceramics Upaya minimasi limbah cair industri keramik dalam perspektif teoritis atau praktis, dikenal dengan beberapa cara yang dapat dilakukan oleh perusahaanperusahaan industri keramik dalam kegiatannya.

Upaya tersebut dapat dilakukan dengan cara pengurangan limbah dan proses daur ulang. Upaya internal dapat dilakukan oleh perusahaan-perusahaan industri keramik sesuai dengan kondisi kemampuannya adalah perencanana proses produksi yang baik, akurat dan cermat mengurangi penggunaan bahanbahan kimia pembantu yang rendah beban pencemaran, pengontrolan pemakaian air yang hemat dan efisien, memanfaatkan dan menggunakan kembali (reuse) bahan-bahan kimia yang terdapat dalam limbah cair untuk keperluan produksi.

Sedangkan upaya eksternal yang dilakukan oleh perusahaanperusahaan industri keramik adalah upaya memantau limbah hasil pasca proses kegiatan minimasi limbah.

\section{Kesimpulan}

Dari penelitian yang telah penulis lakukan mengenai aspek hukum pengelolaan limbah rumah pabrik dalam rangka pencegahan pencemaran lingkungan di PT Sango Ceramics Indonesia, maka penulis mengambil beberapa kesimpulan :

1. Aspek hukum pengelolaan limbah ramah pabrik di PT. Sango

\section{Ceramics}

Penataan hukum lingkungan di Indonesia khususnya dalam hal penegakannya masih belum efektif terbukti dengan adanya pembuangan limbah industri yang dilakukan oleh PT. Sango Ceramics di Semarang yang mengakibatkan tercemarrnya air yang berada di lingkungan sekitar pabrik yang menimbulkan keresahan warga sekitar, dimana air merupakan hal yang sangat penting dalam menunjang kehidupan manusia. Ada banyak sekali langkah penegakan hukum yang dapat dilakukan mulai dari sanksi administratif, sanksi keperdataan dan sanksi kepidanaan. Sebab dalam menerapkan sanksi hukum sebaiknya dijatuhkan sanksi yang tepat serta dapat mencakup komposisi dari fungsi hukum itu sendiri seperti kepastian, kemafaatan, dan keadilan serta tidak menimbulkan kerasahan pada masyarakat. Aspek hukum pencemaran lingkungan hidup akibat buangan limbah industri menjadi perhatian yang tidak pernah surut semenjak diberlakukannya UndangUndang Nomor 4 Tahun 1982 yang kemudian diubah menjadi UndangUndang Nomor 423 Tahun 1997 tentang Pengelolaan Lingkungan Hidup. Semakin banyak kasus pencemaran lingkungan hidup akibat buangan limbah industri, hal tersebut sangat mengganggu dan meresahkan kehidupan masyarakat serta mengancam kelestarian fungsi lingkungan hidup. Pencemaran lingkungan hidup secara teoritis tersebut timbul apabila suatu zat atau energi dengan tingkat konsentrasi yang sedemikian rupa sehingga dapat mengubah kondisi lingkungan.

\section{Upaya pencegahan serta solusi terhadap timbulnya pencemaran lingkungan}

Upaya PT. Sango Ceramics untuk minimasi pencemaran limbah dilakukan 
dengan cara pengurangan limbah dan proses daur ulang. Upaya internal dapat dilakukan oleh perusahaanperusahaan industri keramik sesuai dengan kondisi kemampuannya adalah perencanana proses produksi yang baik, akurat dan cermat mengurangi penggunaan bahanbahan kimia pembantu yang rendah beban pencemaran, pengontrolan pemakaian air yang hemat dan efisien, memanfaatkan dan menggunakan kembali (reuse) bahan-bahan kimia yang terdapat dalam limbah cair untuk keperluan produksi. Sedangkan upaya eksternal yang dilakukan oleh PT. Sango Ceramics adalah upaya memantau limbah hasil pasca proses kegiatan minimasi limbah.

\section{Saran}

Sebaiknya PT. Sango Ceramics melakukan pengolahan limbah yang seharusnya di lakukan, agar limbah yang dihasilkan tidak berdampak pada hal negatif saja akan tetapi mempunyai dampak positif berdasarkan pengolahannya, diperlukan regulasi serta jalur koordinasi yang kuat pada pihak PT. Sango Ceramics untuk memperhatikan setiap limbah yang dihasilkan agar bisa dinetralisir sebelum di buang ke lingkungan. Hal tersebut sangat berpengaruh pada keadaan baik dari segi aspek lingkungan maupun masyarakat.

Untuk mencegah pencemaran lingkungan hidup maka dibutuhkanlah pengelolaan limbah yang baik dan benar, pengelolaan limbah diatur dalam Pasal 59 Undang-Undang Nomor 32 Tahun 2009 mengenai pengelolaan limbah bahan berbahaya dan beracun, yang dilakukan dengan :

1. Setiap orang yang menghasilkan limbah B3 wajib melakukan pengelolaan limbah B3 yang dihasilkannya.

2. Dalam hal B3 sebagaimana dimaksud dalam Pasal 58 ayat (1) telah kedaluwarsa, pengelolaannya mengikuti ketentuan pengelolaan limbah B3.

3. Dalam hal setiap orang tidak mampu melakukan sendiri pengelolaan limbah B3, pengelolaannya diserahkan kepada pihak lain.

4. Pengelolaan limbah B3 wajib mendapat izin dari Menteri, Gubernur, atau Bupati/Walikota sesuai dengan kewenangannya.

5. Menteri, Gubernur, atau Bupati/Walikota wajib mencantumkan persyaratan lingkungan hidup yang harus dipenuhi dan kewajiban yang harus dipatuhi pengelola limbah B3 dalam izin.

6. Keputusan pemberian izin wajib diumumkan.

7. Ketentuan lebih lanjut mengenai pengelolaan limbah B3 diatur dalam Peraturan Pemerintah.

Penerapan sanksi yang tepat dalam kasus ini adalah sanksi keperdataan berupa penggantian kerugian yang nantinya dapat digunakan sebagai alat untuk merehabititasi lingkungan agar dapat kembali seperti semula. Sebab yang mengalami dampak terbesar dalam pencemaran tersebut adalah masyarakat di sekitar pabrik tersebut. Sehingga jika tidak dilakukan pemulihan lingkungan tersebut maka masyarakatlah yang akan menderita dan pengusaha atau pemilik pabrik tersebut tidak mengalami dampaknya.

\section{Daftar Pustaka}

Literatur

Komar kantaatmadja, Bunga Rampai Hukum Lingkungan Laut Internasional, PT Alumni 
Muhamad Erwin, Hukum Lingkungan Dalam Sistem Kebijakan Pembangunan Lingkungan Hidup, Refika Aditama, Bandung, 2008

Muhamad Sadi is, Hukum Perusahaan di Indonesia, Jakarta, Kencana,2016,

M. Yahya Harahap, 2004, Beberapa Tinjauan Sistem Peradilan Dan Penyelesaian Sengketa, Bandung: PT. Citra Aditya Bakti

Mas Achmad Santosa dkk., Penerapan Asas Tanggung Jawab Mutlak di Bidang Lingkungan Hidup, Dalam (undang-undang nomor 23 tahun 1997 dan Permasalahannya), Proyek Pembinaan teknis Yustisial Mahkamah Agung RI, Jakarta, 1998, Hlm. 123

Muhamad Syarif Nuh, Hakikat Pertanggung Jawaban Pemerintah Daerah Dalam Penyelenggaraan Pemerintah, fakultas Hukum Universitas Muslim Indonesia Makasar,2010.

Otto Soemarwoto, Ekologi, Lingkungan Hidup dan Pembangunan, Djambatan, 2001

Philip kristanto, Ekologi Industri, Andi, Yogyakarta, 2004

Philipus M. Hadjon, Pengantar Hukum Perizinan, Surabaya, Yuridika, 1993

Ridwan HR, Hukum Administrasi Negara, Jakarta, PT RajaGrafindo Persada, 2006

Rachmadi usman, Pilihan Penyelesaian Sengketa di Luar Pengadilan. Citra Aditya Bakti,Bandung, 2013

Rochmani, (2018), Hukum Lingkungan dan Penegakkan Hukum, Penerbit Putaka Magister Universitas Stikubank Semarang

Susanti Adi Nugroho, Penyelesaian Sengketa Arbitrase dan Penerapan hukumnya, Kencana, Jakarta, 2015

Takdir Rahmadi, Hukum Lingkungan di Indonesia. PT RajaGrafindo Persada,
2011, hlm

Tim Penyusun Kamus Pusat Pembinaan dan Pengembangan bahasa. Kamus besar Bahasa Indonesia. 1988, Jakarta, Departemen Pendidikan dan Kebudayaan Republik Indonesia, hlm $611 \mathrm{TM}$.

Lutfi Yazid, Penyelesaian Sengketa Lingkungan (Environmetal Dispute Resolution), Surabaya: Airlangga University Press-Yayasan Adikarya IKAPI-Ford Foundation, 1999

Witanto, Hukum Acara Mediasi, alfabeta, 2011

\section{Jurnal}

Hidayat, (2014), Analisis yuridis terhadap pencemaran lingungan menurut UU RI No 32 Tahun 2009 tentang perlindungan dan pengelolaan lingkungan hidup, Jurnal UIN Alaudin Makassar

Hasibuan, (2016), analisis dampak limbah/sampah rumah tangga terhadap pencemaran lingkungan hidup, Jurnal Ilmiah Advokasi

Widyaningtyas dkk, (2014) Analisa Kasus Penerapan Pasal Pada Undang - Undang No.32 tahun 2009 Tentang Perlindungan dan Pengelolaan Lingkungan Hidup Dalam Kasus Pembuangan Limbah Pabrik Tekstil ke Sungai Citarum, Universitas Brawijaya Malang

\section{Website}

https://id.wikipedia.org/wiki/Hukum_lin gkungandi akses tanggal 29 januari 2018https://www.kompasiana.com/lol oks/5a23063ffcf6813f2e2319f2/tangg ungjawabperusahaan-danmasyarakatterhadaplingkungandiaksespada tanggal 30 januari 2018 